to the dispositions of thought and action learnt by individuals. This occurs through processes of enculturation or socialization that an individual goes through as they grow up within a social context. Some of the characteristics of transmitting embodied capital are that its learning cannot be delegated (I cannot outsource, for instance, the process of learning dinner table etiquette in the same way that I can for the making of my clothes), its learning is time intensive and cannot be transmitted instantaneously like a gift or commodity, and can involve the same deliberation over opportunity costs that comes with any kind of investment. This last point relates not only to choices made between different cultural activities (watching television vs attending an art gallery), but also the length of time and economic capital that an individual or family can devote to "accumulating" cultural capital. As Bourdieu puts it, embodied cultural capital represents "external wealth converted into an integral part of the person."

Objective cultural capital refers to material objects such as books, artworks, musical instruments, etc., the consumption of which presupposes an already existing level of cultural capital. The possession of a book, for instance, presupposes an ability to read, just as displaying an artwork presupposes some degree of artistic appreciation. Finer social distinctions are possible in each case. A celebrity magazine, for instance, is appreciated by its readers on terms that are different to that of a novel or a travel guide. What is perhaps even more significant, however, is that different modes of cultural consumption are relationally constituted and not necessarily fixed or inherent to the objects themselves. Thus the same celebrity magazine may be read more or less ironically depending upon how conscious the reader is of it being "trashy," and at the same time an artwork may be derided for being out of touch with the tastes of a particular social group. In each case the social position of the consumer, meaning where their relative degree of cultural or economic capital places them within the social field (rich philistine, poor bohemian, conservative working class, etc.), becomes a key factor in how an object is encountered, interpreted, and used. In this sense, depending on the social context, the disposition of the group or person, and their relative social position, the same object may be appropriated as a marker of social privilege and domination, empowerment and resistance, or an object of embarrassment and social domination (what Bourdieu would call symbolic violence).

As Bourdieu describes it, institutional capital can be thought of as a form of objectified cultural capital that is created and regulated by formal institutions, often as condition of access to otherwise exclusive positions of privilege. Examples include degrees, awards, titles, or qualifications, which may afford entry into professionalized practices such as teaching, architecture, law, and medicine; access to clubs and associations; or simply provide honorary symbols of one's social position. Institutionalized cultural capital acts as a social marker in the same way as other form of objective capital; however, it has added effect of conferring lasting markers of difference beyond one embodied state. A person can still hold a Bachelors qualification, for instance, even if the knowledge and skills used to acquire it have long been forgotten.

\section{References and further reading}

Bourdieu, Pierre. "The Forms of Capital." In J. Richardson (Ed.), Handbook of Theory and Research for the Sociology of Education. New York: Greenwood, 1986, pp. 241-58.

Bourdieu, Pierre and Jean-Claude Passeron. Reproduction in Education, Society and Culture. Trans. Richard Nice. London: Sage Publications, 1977.

Matt Kiem

See also Aesthetics; Class.

\section{CULTURAL RELATIVISM/CULTURAL DIFFERENCE}

Cultural relativism, like cultural absolutism or cultural pluralism, refers to a theoretical system for classifying and understanding human variation. The concept of cultural relativism emerged as a set of descriptive and epistemological precepts within American anthropology in the late nineteenth and early twentieth centuries and, more broadly, in the course of the decline of polygenetic and biological-racial explanations for human variation. More recently, it has become central to debates over legal and political norms, particularly around multiculturalism, the politics of race and racism, and international human rights law. As a taxonomic system, cultural relativism involves a culturalist iteration of some key tenets of earlier, biological accounts of race, such as essentialism, fixity, comparability, and ranking. Because of this, while cultural relativism is often associated with valuing cultural differences, it does not necessarily draw 


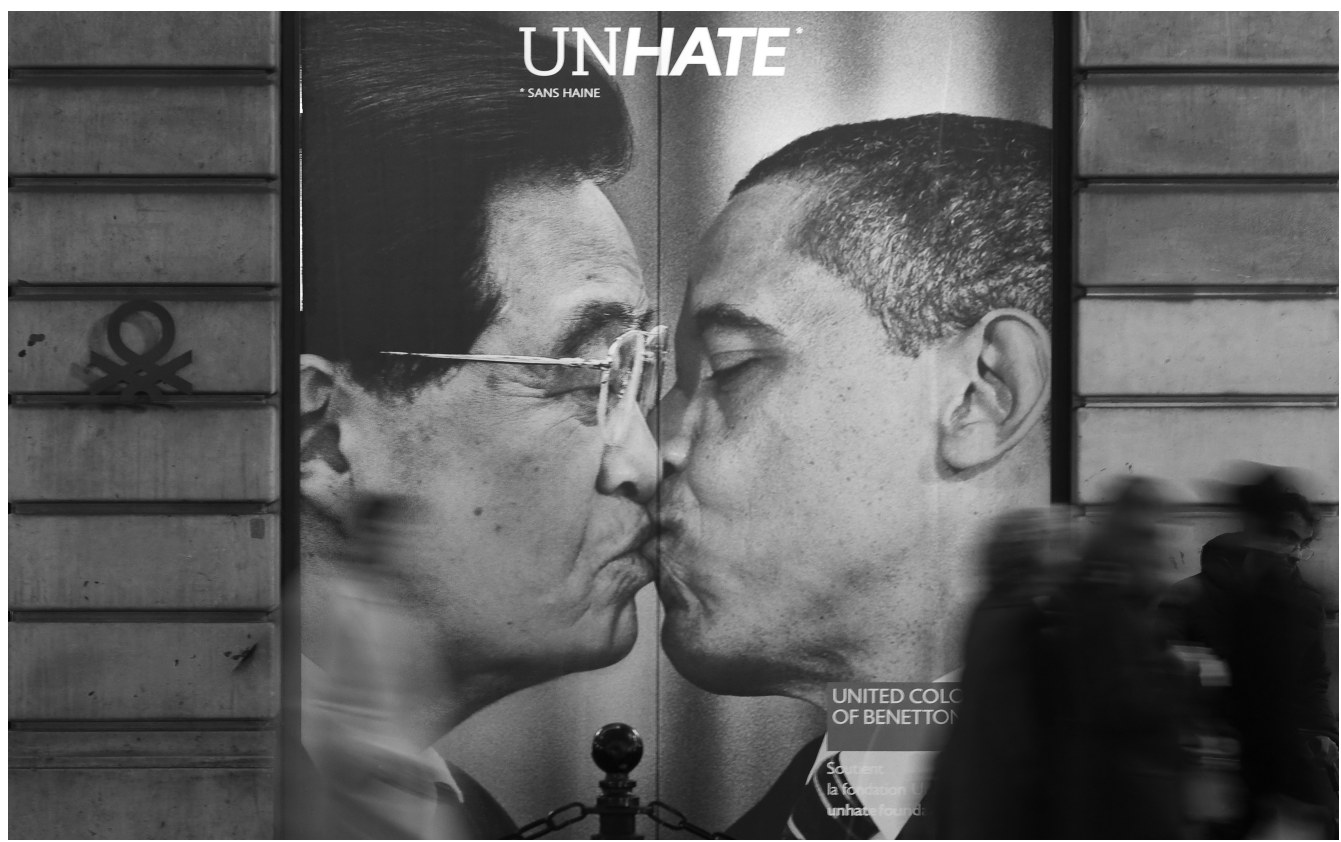

Advertisement for Benetton's new advertising campaign entitled "Unhate" in Paris, November 17, 2011 showing US President Barack Obama and the Chinese leader Hu Jintao. (C) IAN LANGSDON/epa/Corbis.

antithetical prescriptive or organizational inferences from those of cultural absolutism or genetic-racial theories of human difference.

\section{Cultural difference}

To understand how cultural relativism emerged and works as a system of classification, it is important to understand what is distinctive about the basic unit into which it groups and through which it comprehends human variation. It often pertains to debates regarding the ascription and arrangement of particular and universal cultural traits within a larger classification system. Yet the use of "culture" as a way of grouping and then comparing, ranking, or relating human variations both is historically recent and has particular implications. Among other things, it posits that cultures-as with races-can be attributed with unique, preexisting properties, and that the question to be answered (through relativism, absolutism, pluralism, etc.) is that of the organizational or evaluative rules of a subsequent encounter with external differences.

The word "culture" is derived from the Latin "cultura," meaning "cultivation." This agricultural sense is retained in contemporary biology (as in "tissue culture"), and in its figurative association with civilization or improvement, as in "cultured." There are immense and ongoing debates in a range of scholarly fields about what culture means (Bottomore, 1962; Harris, 1968; Nelson and Grossberg, 1988; Taylor, 1989; Keesing, 1990; Donald and Rattansi, 1992; Young, 1995; Malik, 1996; Fowler, 1997; Castro-Gomez and Johnson, 2000; Muller, 2005). Across the twentieth century, culture has been used to refer to anything from the extrasomatic, environmental influences, beliefs, and customs, through to art, literature, emotions, or ideas.

The argument that culture is determinative is necessary but not sufficient to establish an argument for either cultural relativism or cultural absolutism. To be able to posit a relative (absolute, or other kind of) ordering between singular and discrete cultures it is necessary to assume the factual existence of indivisible, transmissible, or heritable, nonbiological human variations. In this sense, cultural relativism is, as with cultural absolutism, premised on the anthropological concept of kinship as a key causal mechanism of cultural transmission, in contrast to that of genetic theories of racial inheritance. For the American cultural anthropologist Margaret 
Mead (1901-78), culture is "the systematic body of learned behavior which is transmitted from parents to children" (Benedict, 1934, p. vii). The European anthropologist Bronisław Malinowski (1884-1942) similarly defined culture as "the organisation of human beings into permanent groups," involving "inherited artifacts, goods, technical process, ideas, habits and values" (1944, pp. 621-46). As with cultural absolutism and cultural pluralism, theories of cultural relativism are predicated on the historical emergence of a distinctively cultural understanding of the following: theories of the causal mechanisms and origins of human variation; explanations of the persistence of those variations as a set of unique habits or customs over time (as heritable or transmissible); and operating principles or rules regarding the trans- or intracultural ranking and ordering of anthropic diversity.

The first two of these founding assumptions of cultural relativism, often referred to as descriptive or epistemological cultural relativism, came to be seen as facts during the period of the European Enlightenment, the French and American revolutions, the enormous expansion of the trans-Atlantic slave trade, mass migrations, industrialization, the rise of the British empire, and the growth of settler colonies. It is in these tumultuous times that the use of the term "a culture," in the sense described above, first appears in eighteenth-century Europe (Kroeber and Kluckhohn, 1952, p. 145).

By the early twentieth century, Ruth Benedict's Patterns of Culture had established the canonicaland arguably the current, popular-definition of culture as a coherent system of psychosocial beliefs, values, and practices. This definition is a methodological and taxonomic one, in that it renders the object of ethnographic research amenable to the methods of comparison and ranking. It also implies homogeneity. Culture, according to Benedict, takes the typological and isometric form of an individual "personality-writ-large." Each individual is a fractal or scalar instance of a larger-scale culture that, in turn, is both figuratively personified and understood as having a personality. Moreover, arguing from comparisons of "primitive" cases (the Zuni in the southwestern United States, the Dobuans in Melanesia, and the Kwakiutl in western Canada), which she suggested existed at lower orders of complexity, Benedict contended that it was possible to infer from such cases what is "specific to local cultural types and those that are general to mankind" (1934, p. 20). It is these anthropological methods that would serve as the template for subsequent debates about cultural relativism in the field of international and national law.

Prior to and beyond Benedict's contribution to the formalization of a theory of culture, it was the confluence of European Enlightenment ideas about universal human progress, the decline of polygenetic and biological explanations of human variation across the nineteenth and twentieth centuries, and the search for alternative accounts for the persistence of inequality that "culture" began to assume a central explanatory importance (Young, 1995; Lentin, 2005). It is these historical shifts that gave rise to debates around the normative or prescriptive dimensions of cultural relativism (and cultural absolutism), specifically around the formulation of legal principles or rules regarding the trans- or intracultural ranking, ordering, and explanation of human differences.

It should be noted that not all studies of culture or uses of that term define it in these ways. Cultures are not always understood in anthropic or human-centric terms, as heritable, homogeneous, and scaled-up versions of singular personalities. A number of studies of culture are either critical of or do not follow the key elements of this approach (Nelson and Grossberg, 1988; Mayer, 2000; Barber and Clark, 2002; Jones, 2003; Thacker, 2005; Berlant, 2008). It is because Benedict's definition of culture facilitates comparability, reproduction, and ranking that the framework of cultural relativism (or absolutism) can serve as a means to diagram political representation that remains modeled on theories of racial reproduction. Roderick Ferguson has argued, "by rejecting biology as the domain of difference in favor of culture... rather than neutralizing racism" a "liberal social science" in the United States "inscribed the racial difference of African American culture as one that rotated around the centrality of heteronormativity" (2004, p. 88).

\section{Early cultural relativism}

The term "cultural relativism" was coined by the AfricanAmerican philosopher Alain Leroy Locke (1885-1954), in a critical review of the American anthropologist Robert Lowie's book Culture and Ethnology (1929). Students of the German-American anthropologist Franz Boas (1858-1942), such as Lowie and Ruth Benedict, expanded on Boas' argument that "civilization is not something absolute, but ... relative, ... our ideas and conceptions are true only so far as our 
civilization goes" (Powell and Boas, 1887, p. 156). Unlike pre-eighteenth-century accounts of human variation, Boas' argument highlights the growing importance of a question about variation over time. It is a question that would be increasingly posed in linear or teleological terms as a question about civilization, progress, or, alternately, as one of decline and degeneration (Young, 1995). In this respect, the definition of culture recalls its association with the temporal and progressive understandings of "cultured." Thus, while A. L. Locke took issue with Lowe's "extreme cultural relativism," both nevertheless agreed on the premise of unique cultures situated within a framework of single origins and an aspirational tendency toward universality (Helbling, 1979).

During Boas' time, the prevailing view of human origins and variation in American anthropology was one of racial polygenism (Bernasconi, 2002), whereby human variations were explained in terms of separately created species constituting discrete lineages, immutable, and positioned within an ontological hierarchy, often referred to as the "Chain of Being." The "Chain of Being" (or scala naturae) was a neo-Platonist taxonomy developed by Catholic theologians in Classical Antiquity (Lovejoy, 1936). The neo-Platonism of the physical anthropologist Josiah Clark Nott (1804-73) was largely turned toward the legitimation of slavery in pre-Civil War southern American states: "the negro achieves his greatest perfection, physical and moral, and also greatest longevity, in a state of slavery" (Dewbury, 2007, p. 124). Conversely, slavery abolitionists such as Frederick Douglass argued from a Biblical theory of monogenesis (single creation), countering polygenetic argument for slavery by insisting that "what are technically called the negro race, are part of the human family, ... descended from a common ancestry," and, furthermore, that the progressive annihilation of "time and space, in the intercourse of nations" would give rise to a "common humanity" (1854, pp. 10-11).

Boas' cultural relativism largely accords with the progressive argument put forward by Douglass and given credence by the rise of the evolutionary theories of Charles Darwin (1809-82). Significantly, Boas reread these through the prism of the cultural nationalist theories of the eighteenth-century German philosopher and theologian Johann Gottfried Herder. According to Herder, nations did, and should, represent the authentic and ultimately incommensurable cultural heritages. These differences could be integrated under a "common humanity," up to a point. As Robert Young argues, "Herder's relativism was itself a sign of the Romantic questioning of the dominant Enlightenment ethos of civilization, [universal] progress, perfectibility-and equality" (Young, 1995, p. 40). In this sense, Boas in no way could be said to have supported slavery; but with its abolition and the decline of polygenistic accounts of human origins, the systems of segregation that emerged in the wake of the American Civil War, officially at least, were increasingly justified through arguments of cultural relativism. The "Jim Crow" laws enacted in the American South after the Civil War, which remained in force until 1967, mandated the segregation of public spaces and utilities on the basis of the doctrine of "separate but equal" (Massey and Denton, 1993).

\section{Cultural relativism in the twentieth century}

From the perspective of a formal, legal emphasis on cultural differences, cultural relativism could be seen as a way of representing cultural diversity through the state, as with multiculturalism. On the other hand, cultural relativism could be proffered as an argument for "separate development," as with Apartheid in South Africa, or "Jim Crow" laws in the southern United States; or it could be invoked as the premise of cultural nationalism (or ethno-nationalism). This is not to suggest these are the same; rather that versions of cultural relativism can be invoked to argue for any of these as state-legal responses to preexisting cultural differences. While cultural relativism, then, can often imply the suspension of value judgments about cultural differences, varieties of cultural relativism can have both ambivalent and, at times, vastly disparate consequences when given legal or normative form.

The combination of anthropological methods and normative legal arrangements reached its height in the wake of Second World War, and in attempts to counter and replace biological theories of race, particularly since these were regarded as conducive to the rise of German National Socialism and the subsequent Holocaust (Lentin, 2005). While some have argued that National Socialism adhered to nonbiological, neo-Platonist understandings of race (Forti, 2006), as Martin Barker has illustrated, within the United Nations (and UNESCO) a Boasian view of racism as founded on biological theories of race prevailed and shaped the uptake of cultural relativism (1982). For Barker and others (Barker, 
1982; Taguieff, 1988; Balibar and Wallerstein, 1991; Gilroy, 1991, 1993), contemporary racism emphasizes intractable cultural differences, or presents cultural differences as explanations of social and economic inequality (Leacock, 1971; Lewis, 1981), diverging from multiculturalism less in the way of its premises than in the status it accords to progressive integration under more or less abstract legal-political rules of cultural interaction or uniformity or the explanatory status it accords to heritable cultures. In the latter sense, Dinesh D'Souza has argued that Boasian relativism has been complicit in the perpetuation of racial injustice in the United States (1995). According to Alana Lentin, "culturalist approaches to explaining and proposing solutions to racism are inadequate because they avoid the political relationship of 'reciprocal determination' between 'race' and state" (2005, p. 392). Moreover, as Michael Brown notes, extrapolating legal forms of representation from theories of cultural difference inclines toward "[in]sensitivity to the rights of minorities within larger social units" (2008, p. 366), and inasmuch as "cultures" are seen as homogeneous entities.

\section{Cultural relativism in contemporary debates}

More recently, it is in the context of debates over international (human rights) law, the "War on Terror," and humanitarian military interventions that cultural relativism (and the role of anthropology) has once again become a matter of significant debate (Hastrup et al., 2000; Brown, 2008). In the case of the "War on Terror," William Bennett has argued that cultural relativism "implies that we have no basis for judging other peoples and cultures, and certainly no basis for declaring some better than others, let alone 'good' or 'evil'" (2002, p. 46). By contrast, Wendy Brown has argued against the precept of "liberal tolerance" as an instance of "Western superiority" that seeks to "legitimate Western cultural and political imperialism" (2006, p. 7).

Cultural relativism has been criticized for legitimating human rights abuses and defended as a counter to those abuses (Hastrup et al., 2000; Cowan, Dembour, and Wilson, 2001). Lila Abu-Lughod has suggested, in the case of assumptions about the status of Muslim women, for people to be "respectful of other paths toward social change" (2002, p. 788). Similarly, for Clifford Geertz, there are far fewer adherents of cultural relativism than there has occurred, in politics, a resurgence of anticultural relativist campaigns that seek to reinstate a form of cultural absolutism (1984).

In summary, "cultural relativism" is a placeholder for circumstantial or localized debates about power, racism, and proposed or current laws and political arrangements sifted into the language of cultural difference and suppositions about cultural universality and transcendence. For instance, Michael Brown argues that cultural relativism overstates "the internal coherence of individual cultures" while underestimating "the possibility of transcending these differences" (2008, p. 371). While the project of "transcendence" might be queried, his remarks illustrate the ways in which "culture" has become a prevailing framework through which political and legal questions are posed and contested in a simultaneously temporal and culturalist register. In this form, they are reliant on a classification systems hinged around a slippage from "race" to terms such as "culture" or "ethnicity," with many of the same premises, namely: fixed assumptions about what are considered to be universal or particular (and therefore internally homogeneous, bounded, and heritable) cultural traits.

\section{References and further reading}

Benedict, Ruth. Patterns of Culture. Boston, MA and New York: Houghton Mifflin Company, 1934.

Brown, Michael F. "Cultural Relativism 2.0," Current Anthropology, 49.3 (2008): 363-383.

Brown, Wendy. Regulating Aversion: Tolerance in the Age of Identity and Empire. Princeton, NJ: Princeton University Press, 2006.

Dewbury, Adam. "The American School and Scientific Racism in Early American Anthropology," Histories of Anthropology Annual, 3.1 (2007): 121-147.

Douglass, Frederick, Western Reserve College (1826-1882), and African American Pamphlet Collection (Library of Congress). The Claims of the Negro, Ethnologically Considered: An Address before the Literary Societies of Western Reserve College, at Commencement, July 12, 1854. Rochester, NY: Press of Lee, Mann \& Co, 1854.

Ferguson, Roderick A. Aberrations in Black: Toward a Queer of Color Critique. Minneapolis: University of Minnesota Press, 2004.

Lentin, Alana. 'Replacing 'Race,' Historicizing 'Culture' in Multiculturalism," Patterns of Prejudice, 39.4 (2005): 379-396.

Malinowski, Bronislaw. A Scientific Theory of Culture. Chapel Hill, NC: The University of North Carolina Press, 1944. 
Powell, J. W. and Franz Boas. "Museums of Ethnology and Their Classification," Science, 9.229 (1887): 612-614.

Young, Robert. Colonial Desire: Hybridity in Theory, Culture, and Race. London and New York: Routledge, 1995.

Angela Mitropoulos

\section{CULTURE, THEORIES OF}

As Raymond Williams (1983) states in Keywords, the complexity of "culture" derives from its intricate historical development across multiple European languages as well as how it is used in different and often incompatible ways by distinct systems of thought. As Robert Young (1995) reveals, any reference to either "culture," "a culture," or "our culture" has always presupposed or posited an "other" whether that be the uncultured, the lesser-cultured, or the other-cultured. Young insists that "culture" was "invented for difference," arguing that the first anthropological use of the word in English was in the context of the American Civil War in which Anthony Trollope recorded a cultural difference between North and South. This divisive logic of culture has been significant to the experience of modernity, particularly in terms of the material and ideological contradictions that unfolded in the interplay of Enlightenment thinking, capitalism, social elitism, and colonialism.

\section{The etymology of "culture"}

Complications with the term "culture" are reflected in its Latin derivation. Cultura and colere had a range of meanings, including to inhabit, cultivate, attend, protect, and honor with worship. These meanings gave rise to additional concepts that often retain uncanny and revealing connections. The "honor with worship" theme was refined to cultus, from where both "cult" and the French couture are derived, and the "inhabit" meaning developed into colonus (farmer), from where the term "colony" is derived. This is significant to the history of colonialism, particularly as this relates to and incorporates the political function of the city. Early English uses of "culture" related predominantly to agricultural practices of the tending to or cultivation of plants and animals. The sedentary economic practices of farming, the surpluses they produced, and the hierarchies that appropriated them, were a condition for the development of urban social forms. This is retained today in a sense of cities as centers of culture. The spatial effectthe demarcation of occupied land, the physical and symbolic construction of boundaries, and the establishment of land-based property systems - set early formations of culture in antagonistic relation to nomadic peoples, a rift previously encoded in both classical and biblical thought (the citizen of the Greek polis versus the external barbarian, and the slaying of the sheep herder Abel by his crop farming brother, Cain).

\section{Culture as "improvement" and "civilization"}

The modernist notion of teleological improvement over time added a temporal dimension to culture's spatiality. "Culture" became synonymous with Eurocentrically defined conceptions of "civilization" that were used as justification for imperialist domination. This began in the sixteenth century when the concept of cultivating land shifted into the notion of human development or the "cultivation of the mind." In the eighteenth century this was further abstracted into the process of becoming "cultivated" or "cultured" in the sense being "refined" or "educated." Culture as civilization was unilinear and teleological in the sense that it posited a singular and ideal end-point upon which all humans were said to be converging. European identity was shaped by historical narratives of developmental stages, intellectual and economic, that mirrored and interweaved ideas of natural evolution, organic growth, childhood development, and racial hierarchy. This, for example, was the intellectual scaffold that Adolf Loos (1908) would use to construct his polemic against ornamentation: "The human embryo in the womb passes through all the evolutionary stages of the animal kingdom. When man is born, his sensory impressions are like those of a newborn puppy. His childhood takes him through all the metamorphoses of human history. At 2 he sees with the eyes of the Papuan, at 4 with Teuton, at 6 with those of Socrates, at 8 with those of Voltaire."

Loos' reference to Voltaire reflects the ambivalent influence of Enlightenment thinkers. While acknowledging the damaging consequences of their Eurocentricism, Young still notes the presence of radically egalitarian ideas, including the notion that every individual, regardless of ethnicity, was both capable and entitled to "improve" themselves through education. What it meant to "improve" oneself, however, was ethnocentrically determined and imposed. The "civilizing mission" thereby became a foil for imperial expansion. Methods 